\title{
Study on Comparison between Enzyme Wash and Bleach Wash (Traditional vs. Sustainable Washing Machine) the Physical and Color Fastness to Rubbing Properties of Denim Garments
}

\author{
Shohidul Islam Shamim*, Md. Iusuf Khan, Shaukat Hossan, Mohammed Reaz Uddin \\ Department of Textile Engineering, Port City International University, Chattogram, Bangladesh \\ Email: *shamimbd1492@gmail.com, iusufkhan50@gmail.com, shaukat.naf@gmail.com, riaztexengr@gmail.com
}

How to cite this paper: Shamim, S.I., Khan, Md.I., Hossan, S. and Uddin, M.R. (2020) Study on Comparison between Enzyme Wash and Bleach Wash (Traditional vs. Sustainable Washing Machine) the Physical and Color Fastness to Rubbing Properties of Denim Garments. Journal of Textile Science and Technology, 6, 123-129. https://doi.org/10.4236/jtst.2020.63010

Received: July 1, 2020

Accepted: August 7, 2020

Published: August 10, 2020

Copyright (๑) 2020 by author(s) and Scientific Research Publishing Inc. This work is licensed under the Creative Commons Attribution International License (CC BY 4.0).

http://creativecommons.org/licenses/by/4.0/

\begin{abstract}
This study focuses on comparison between Enzyme Wash and Bleach Wash (Traditional vs. Sustainable Washing Machine) the physical and color fastness to rubbing properties of denim garments. For this experiment indigo dyed cotton denim garments (trousers) were chosen which were $98 \%$ cotton and $2 \%$ spandex and processed by enzyme with the concentration of $2 \mathrm{~g} / \mathrm{l}$, and the temperature of $45^{\circ} \mathrm{C}$. In another work, enzyme treated denim garments were used for bleach wash with the concentration of $2 \mathrm{~g} / \mathrm{l}$, temperature $45^{\circ} \mathrm{C}$ and those samples have been processed by traditional and sustainable washing machine. After completing process, the sample properties have been compared like rubbing, tearing and tensile properties. After comparing result the color fastness to rubbing of enzyme wash was poor in traditional and sustainable machine and tensile strength, tearing strength properties down in traditional machine but the color fastness to rubbing of bleach wash was good in sustainable machine than traditional machine and a little bit lesser tensile and tearing properties in sustainable process.
\end{abstract}

\section{Keywords}

Denim Garments, Enzyme Wash, Bleach Wash, Sustainability, Tensile and Tearing Strength, C.F to Rubbing

\section{Introduction}

Sustainability in denim washing has become burning issue. Especially in wet 
process, a lot of water, chemicals, and dyes are required. The denim sector is booming worldwide, because of the spread of denim culture. Popularity of denim garments has been increasing day by day in the world market but in denim industry 100 liters of water are used to wash a single pair of jeans during the production process. This translated into the denim industry consuming around 18 billion liters of water per year. Fashion changes but denims are still famous and denim washing is not environment friendly. That's why it's usually done in undeveloped countries where the environment regulations are not demarked clearly [1] [2]. In readymade garments sector garments washing is the new technology. This technology is used to modify the appearance, outlook, comfortability of denim garments and bring old garments effect. The most common denim washing methods are enzyme wash, bleach wash, acid wash, normal wash, stone wash, etc. [3]. Denim is very strong, stiff woven fabric and it is twill weave fabric that diagonal lines of warp and weft float are formed in the surface of fabric that uses colored warp yearn and white weft yearn. Denim is used for jeans, working cloth and casual wear [4]. Many researchers have investigated the effect of enzyme and bleach washing on denim. Enzyme treatment of cellulosic garments degrades cellulose at the ends or in the middle of the cellulose chains, yielding shorter chain cellulose polymers and reduces its mechanical strength. Enzymes are living organisms which attack projecting fibers and hydrolyzed them. As a result, removing color from denim and faded effect is produced. In textile industry, enzymatic treatment removes size materials, starch, to bring high and low abrasion of denim garments, give a cleaner, smooth surface, increase comfort ability and quality of denim garments which are used to replace chemical and mechanical process [5] [6] [7] [8]. Among different techniques of garments washing, bleach is widely used in denim washing to decolorize indigo from denim with the help of bleaching agents but bleaching process has some problem like-bleach decomposes the cellulose, tends to make fabric yellowish and bleaching agent especially chlorine bleaches are harmfully for health and environment [9] [10]. UP, the latest Tonello innovation, radically changes garments washing: reducing liquor ratio, saving water and energy [11].

This work was done for looking for the best option for enzyme and bleach wash by sustainable and traditional washing machine.

\section{Materials and Methods}

\subsection{Materials}

$98 \%$ cotton and $2 \%$ spandex $\left(360 \mathrm{~g} / \mathrm{m}^{2}\right)$, indigo dye cotton fabric was used for this experiment.

Biolase NC-77 (Enzyme), BBNTC-1 (Antibackstaining agent) was used for enzyme wash.

Bleaching powder (Calcium Hypochlorite), Sodium Meta Bi Sulphite (Neutralize) was used for bleach washing. 


\subsection{Methodology}

\section{Enzyme Washing Process with Traditional Washing Machine:}

Enzyme wash was conducted with liquor containing $2 \mathrm{~g} / \mathrm{l}$ enzyme and $2 \mathrm{~g} / \mathrm{l}$ antiback staining agent with the liquor ratio $1: 10$ at temperature $45^{\circ} \mathrm{C}$ for 30 minutes. Then denim garments were washed with hot water and again washed with cold water.

\section{Bleach Washing Process with Traditional Washing Machine:}

Enzyme treated denim garments were conducted with liquor containing $2 \mathrm{~g} / \mathrm{l}$ calcium hypochlorite with the liquor ratio $1: 10$ at temperature $45^{\circ} \mathrm{C}$ for $10 \mathrm{mi}$ nutes. Then denim garments were washed with cold water and then neutralized was done.

\section{Enzyme Washing Process with Sustainable Washing Machine:}

Enzyme wash was conducted with liquor containing $2 \mathrm{~g} / \mathrm{l}$ enzyme and $2 \mathrm{~g} / \mathrm{l}$ antiback staining agent with the liquor ratio $1: 5$ at temperature $45^{\circ} \mathrm{C}$ for $30 \mathrm{mi}$ nutes. Then denim garments were washed with hot water and again washed with cold water.

\section{Bleach Washing Process with Sustainable Washing Machine:}

Enzyme treated denim garments were conducted with liquor containing $2 \mathrm{~g} / \mathrm{l}$ calcium hypochloride with the liquor ratio $1: 5$ at temperature $45^{\circ} \mathrm{C}$ for $10 \mathrm{mi}$ nutes. Then denim garments were washed with cold water and then neutralized was done.

\section{Hydro Extracting and Drying:}

After treatment, the washed denim garments were squeezed in hydro-extractor machine (SHI-FURE, Taiwan) at $2000 \mathrm{rpm}$ for 3 - 4 minutes for removing excess water and then dried in a steam dryer (TRIVENETA GRANDI IMPIANTI, ITALY) at $80^{\circ} \mathrm{C}$ for 40 minutes. Then tensile test and color fastness to rubbing were evaluated to determine product performance.

\subsection{Testing Methods}

The treated samples were condition at $65 \% \mathrm{RH}$ and at $20^{\circ} \mathrm{C}$ for $24 \mathrm{~h}$ before testing according to ASTM D1776. Tensile and Tearing test were determined by ASTM D 5034 and ASTM D 1424. Color fastness to rubbing test was determined by ISO 105 .

\section{Results and Discussion}

From view of washed denim garments (Figures 1-4), it has been seen that more enzyme effect by traditional washing machine but good bleach effect seen by sustainable machine.

\subsection{Effect of Enzyme and Bleach Wash on Tearing Strength by Traditional and Sustainable Machine}

Figure 5 shows that tearing strength in warp and weft direction of sample is less of traditional enzyme wash than sustainable enzyme wash but tearing strength 


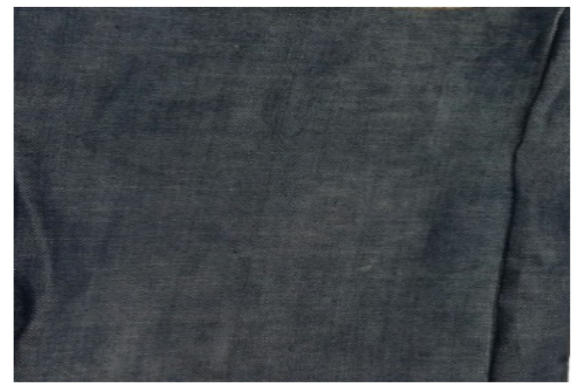

Before wash

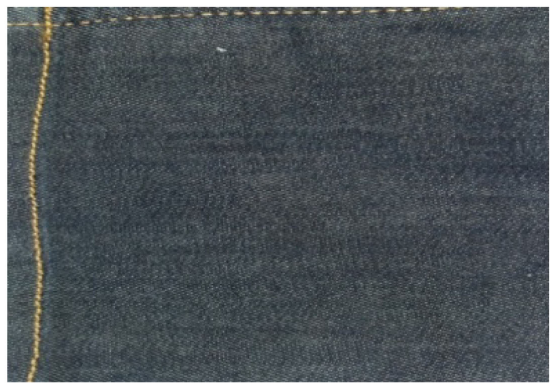

after wash

Figure 1. Enzyme wash effect of traditional machine.

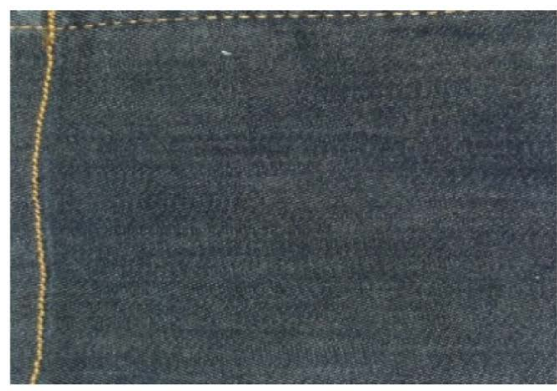

Before wash

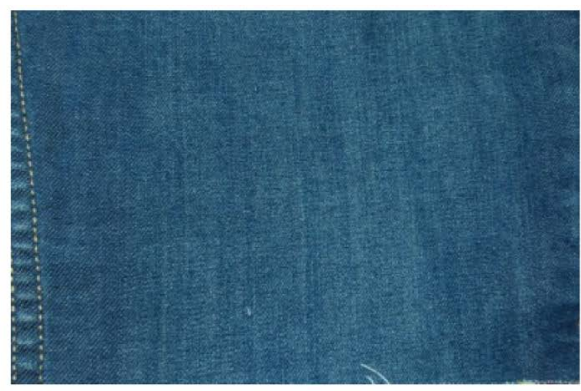

after wash

Figure 2. Bleach wash effect of traditional machine.

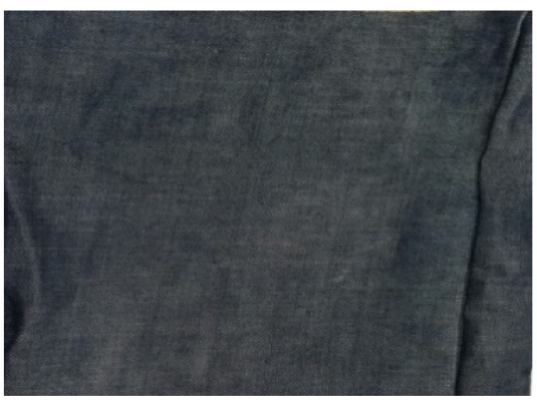

Before wash

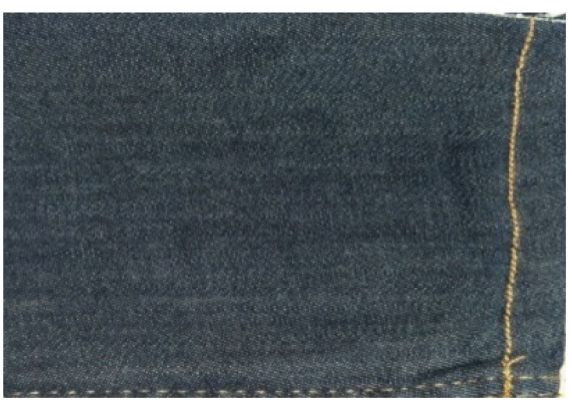

after wash

Figure 3. Enzyme wash effect of sustainable machine.

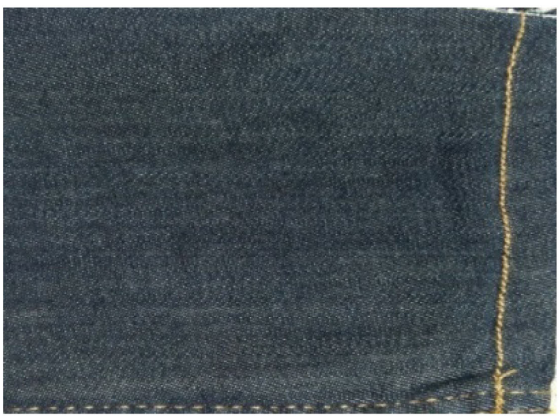

Before wash

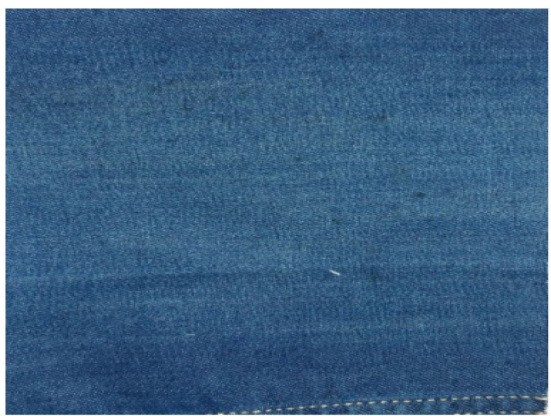

after wash

Figure 4. Bleach wash effect of sustainable machine.

in warp and weft direction of sample is less of sustainable bleach wash than traditional bleach wash. 


\subsection{Effect of Enzyme and Bleach Wash on Tensile Strength by Traditional and Sustainable Machine}

Figure 6 shows that tensile strength in warp and weft direction of sample is less of traditional enzyme wash than sustainable enzyme wash but tearing strength in warp and weft direction of sample is less of sustainable bleach wash than traditional bleach wash.

\subsection{Effect of Enzyme and Bleach Wash on Color Fastness to Rubbing by Traditional and Sustainable Machine}

Figure 7 shows that color fastness to rubbing of enzyme wash was poor in both process but in bleach wash color fastness to rubbing was good in sustainable process.

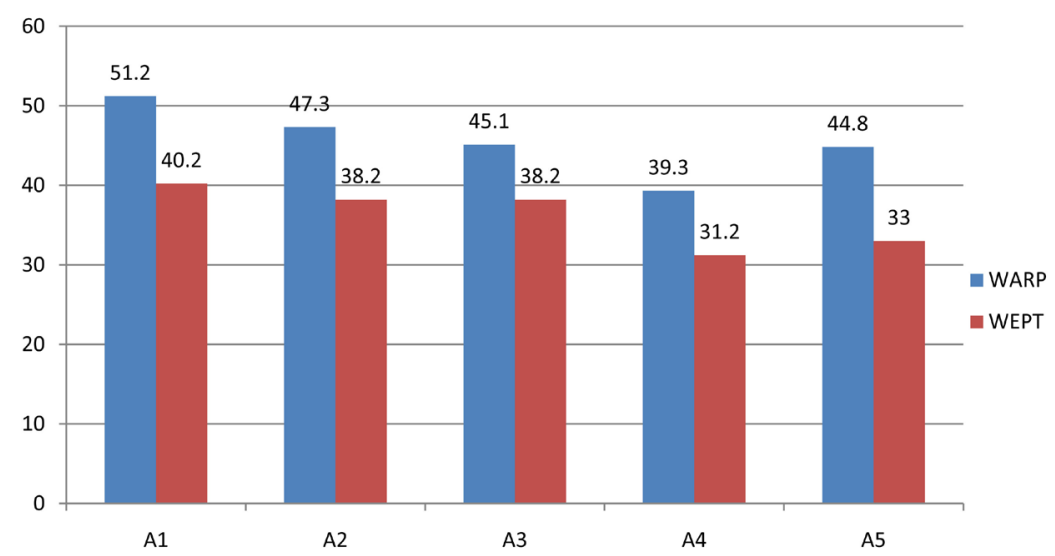

Figure 5. Tearing strength chart. (A1-Before Wash, A2-Sustainable Enzyme Wash, A3-Traditional Enzyme Wash, A4-Sustainable Bleach Wash, A5-Traditional Bleach Wash).

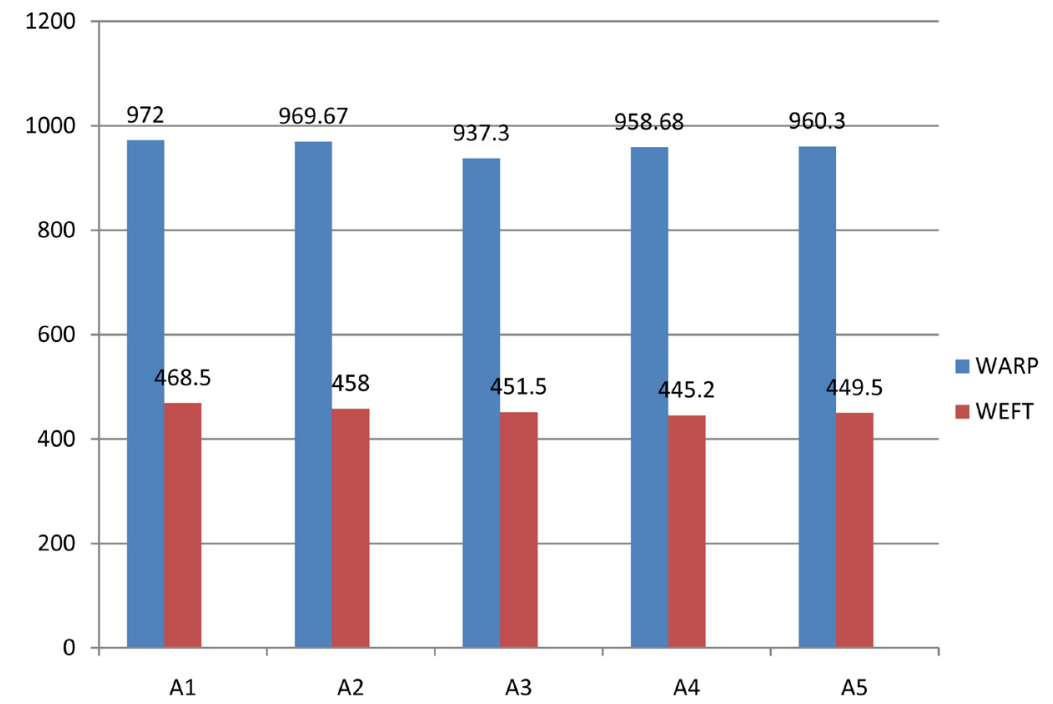

Figure 6. Tensile strength chart. (A1-Before Wash, A2-Sustainable Enzyme Wash, A3-Traditional Enzyme Wash, A4-Sustainable Bleach Wash, A5-Traditional Bleach Wash). 


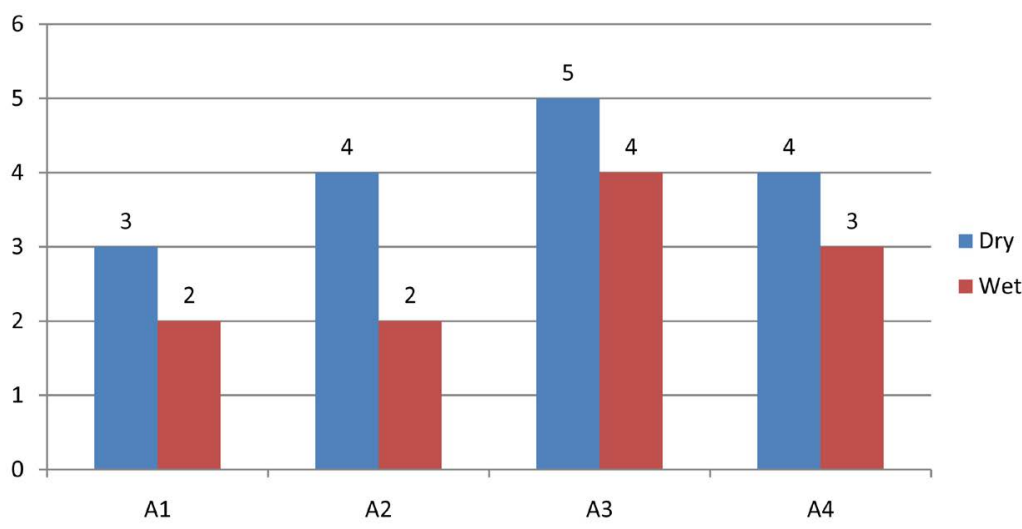

Figure 7. Color fastness to rubbing chart. (A1-Sustainable Enzyme Wash, A2-Traditional Enzyme Wash, A3-Sustainable Bleach Wash, A4-Traditional Bleach Wash).

\section{Conclusions}

This project work was done for looking for the best option for enzyme wash and bleach wash between traditional and sustainable wash. Enzyme and bleach wash by sustainable and traditional machine have more effect on different properties of denim garments. Color fastness to rubbing of enzyme wash is fair in both process but tensile and tearing strength are down in traditional process than sustainable process. Bleach wash by sustainable process has made the greatest influence on properties of sample like color fastness to rubbing is good and a little bit down tensile and tearing properties in sustainable process.

Sustainable wash is far better than traditional wash both from environmental and time context. So, if we can get fewer better enzyme effects from sustainable wash, it will be great for both our apparel and environment sector.

\section{Conflicts of Interest}

The authors declare no conflicts of interest regarding the publication of this paper.

\section{References}

[1] Sustainable Washing. https://www.textiletoday.com.bd/category/industry-best-practices/denim/

[2] Csanák (2014) Sustainable Concepts and Eco-Friendly Technologies in the Denim Industry. International Conference on Design and Light Industry Technology, Hungary Óbuda University, Budapest, November 2014, 1-6.

[3] Khan, M.M.R., Mondal, I.H. and Uddin, Z. (2012) Sustainable Washing for Denim Garments by Enzymatic Treatment. Journal of Chemical Engineering, 27, 27-31.

[4] Zahir, L. and Khan, M.M.R. (2015) Comparison Study of the Effect of Bleaching and Enzyme Concentration on the Physical and Mechanical Properties of Denim Garments. The International Journal of Scientific \& Engineering Research, 6, 343-348.

[5] Heikinheimo, L., et al. (2000) Treating Denim Fabrics with Tri-Choderma Reesei Cellulases. Textile Research Journal, 70, 969-973. 
[6] Rahman, M.M. (2014) Wet Processing-1. Brother's Publications.

[7] Islam, M., Nahar, K., Ferdush, J., et al. (2009) Impact of Bleaching Actions of Bleacing Powder and Hydrogen Peroxide on Biopolished Denim Garments. Tekstil, 68, 35-39.

[8] Morries, C.E. and Harper, R.J. (1994) Comprehensive View on Garment Dyeing and Finishing. American Dyestuff Reporter, 83, 132-136.

[9] Khan, R.M.M., Mondol, H.I., et al. (2011) Effect of Bleach Wash on the Physical and Mechanical Properties of Denim Garments. Proceeding of the International Conference on Mechanical Engineering, 10-12 December 2011, 1-5.

[10] Sarkar, J. and Khalil, E. (2014) Effect of Industrial Bleach Wash and Softening on the Physical, Mechanical and Color Properties of Denim Garments. IOSR Journal of Polymer and Textile Engineering, 1, 46-49.

[11] UP. https://www.tonello.com/en/product/up 